\title{
DISTRIBUTION OF SITES AND RADIOCARBON DATES IN THE SIERRA NEVADA: IMPLICATIONS FOR PALEOECOLOGICAL PROSPECTING
}

\author{
R. SCOTT ANDERSON, ${ }^{1,2}$ SUSAN J. SMITH ${ }^{2}$ and PETER A. KOEHLER ${ }^{3}$
}

\begin{abstract}
The number of paleoecological records for the Sierra Nevada of California has increased substantially since the compilation of Adam (1985). We examine here the geographical and temporal distribution of records within the range in order to identify areas for which "gaps" exist in our paleoecological knowledge. Seventy-two sites with paleoecological information are identified; these sites are dated with 234 radiocarbon dates. Sites occur primarily between $c a .36^{\circ} \mathrm{N}$ and $38^{\circ} 30^{\prime} \mathrm{N}$ latitudes, and from ca. $1000 \mathrm{~m}$ to over $3000 \mathrm{~m}$ elevation on both sides of the Sierran crest, although more sites have been analyzed on the west side of the crest than the east side. In general, packrat (Neotoma) midden series are located at the lowest elevations, meadow and marsh cores originate from mid-elevations, and lake sediments have been analyzed from the highest elevations. Significant gaps in our knowledge occur for much of the east side of the crest, for both sides of the range above modern treeline, and for time periods older than the latest Pleistocene.
\end{abstract}

\section{INTRODUCTION}

Analysis of pollen and plant macrofossils from sedimentary deposits has become an essential tool for the paleoecologist. Beginning in the mid-20th century, the number of sites from eastern North America increased rapidly and they presently number in the hundreds. A similar increase for western North America did not begin until after 1970 (Baker 1983; Barnosky, Anderson and Bartlein 1987), due, in part, to a perceived lack of suitable sites. An increase in the number of researchers examining sediments from high-elevation lakes and meadows, as well as the development of packrat (Neotoma) midden analysis from lower elevations (Betancourt, Van Devender and Martin 1990) has revolutionized our understanding of vegetation change within the more arid regions of western North America.

California is one region in western North America that witnessed little paleoecological research until recently. Adam (1985), which listed and annotated both published and unpublished studies for several regions of the state, was important in identifying "gaps" in our paleoecological knowledge, allowing investigators to provide research bridges between sites and to increase our understanding of paleoenvironments of the past. Here we concentrate on the Sierra Nevada range of California, summarizing and analyzing the recent explosion of information for that region. Our purpose is to identify the location and types of sites that have been most productive paleoecologically, as a logical step in paleoecological "prospecting", to identify possible locations for additional study.

\section{DESCRIPTIVE BACKGROUND}

\section{The Sierra Nevada}

The Sierra Nevada range, oriented with its major axis northwest to southeast, is located almost entirely within eastern California. The range extends almost $575 \mathrm{~km}$ from near Mt. Lassen in the north to Walker Pass in the south, with widths varying from $c a$. 100-125 km. The gentle slopes of $2-6 \%$ on the west side contrast with slopes of almost $26 \%$ on the east side near Owens Valley (Storer and Usinger 1963).

\footnotetext{
${ }^{1}$ Center for Environmental Sciences and Education, Box 5694, Northern Arizona University, Flagstaff, Arizona 86011 USA ${ }^{2}$ Quaternary Studies Program, Bilby Research Center, Box 6013, Northern Arizona University, Flagstaff, Arizona 86011 USA

${ }^{3}$ Present Address: P.O. Box 861, Flagstaff, Arizona 86002 USA
} 
The climate of the Sierra Nevada is Mediterranean, with hot, arid summers and cool, humid winters (Mitchell 1976; Major 1988). Topographic relief and range orientation affects the distribution of temperature and precipitation. Air masses moving from west to east lose moisture as they are forced over the high elevations of the range, causing large precipitation differences between the west and east sides. For a given elevation, precipitation averages nearly twice as much on the west side as on the east (Major 1988).

The Sierra Nevada is today a significant biogeographic boundary, separating the vegetation of the Great Basin from that of the more diverse cismontane Californian Province. Anderson (1990) summarizes the vegetation of the central Sierra Nevada. On the west side a blue oak (Quercus douglassi) and gray pine (Pinus sabiniana) woodland occurs above a grass-dominated prairie zone (to ca. 700$915 \mathrm{~m}$ elevation). The chaparral association, including buckbrush (Ceanothus spp.), manzanita (Arctostaphylos spp.), mountain mahogany (Cercocarpus spp.) and chamise (Adenostema fasciculatum), occurs between ca. 915 and $1225 \mathrm{~m}$. The Sierra montane forest (ca. 1200-2200 m) is dominated by ponderosa pine (Pinus ponderosa), incense cedar (Calocedrus decurrens), black oak ( $Q$. kelloggii), sugar pine (P. lambertiana), and white fir (Abies concolor). Common trees in the upper montane forest (to $c a .2200-2750 \mathrm{~m}$ ) include lodgepole pine ( $P$. contorta var. murrayana), red fir (A. magnifica), sugar pine, western white pine (P. monticola), and Sierra juniper (Juniperus occidentalis ssp. australis). The subalpine forest (to ca. 2570-3200 m) consists of lodgepole pine with mountain hemlock (Tsuga mertensiana), western white pine and whitebark pine (P. albicaulis), with Sierra juniper on exposed locations. On the east side of the crest, limber pine ( $P$. flexilis) replaces whitebark pine. The alpine zone is dominated by herbs and subshrubs.

On the east side of the crest, below the subalpine and upper montane zones described above, a Jeffrey pine (Pinus jeffreyi) woodland is found, often grading at lower elevation into a western juniper (Juniperus occidentalis ssp. occidentalis) and pinyon pine (P. monophylla) assemblage with sagebrush (Artemisia tridentata). Shadscale (Atriplex confertifolia), greasewood (Sarcobatus vermicullatus), and joint-fir (Ephedra spp.) are found in valley bottoms.

\section{Compilation of the Database}

The database for this study consists of a compilation of locations ("sites") where paleoecological significance could be demonstrated. A "site" was considered to have paleoecological significance if 1) chronological control was present, with a minimum of one ${ }^{14} \mathrm{C}$ date, and 2) some indication of sedimentological change (pollen or plant macrofossils, inorganic sediments) was apparent. Most sites include locations where comprehensive studies of pollen and/or plant macrofossil stratigraphies were conducted. Rarely, some sites include only dated stratigraphic profiles.

Sites (with the associated ${ }^{14} \mathrm{C}$ dates) used in this analysis were compiled from various sources. The published literature on Sierra Nevada paleoecology was perused, yielding data on individual ${ }^{14} \mathrm{C}$ dates. Only those records analyzed specifically for paleoecological information were included in this study; sites designated primarily as archaeological were excluded. Unpublished data were integrated from various sources. Much of the data from unpublished sites was readily available and was analyzed by one or more of the authors of this paper.

\section{RESULTS AND DISCUSSION}

Sites compiled for this study are located primarily within the central and southern portions of the Sierra Nevada (Fig. 1). Paleoecological studies have been conducted on both sides of the Sierran crest, as well as from one site on the crest itself. Sedimentary deposits analyzed include lakes, meadows, marshes, packrat middens and, in one case, an archaeological excavation. 


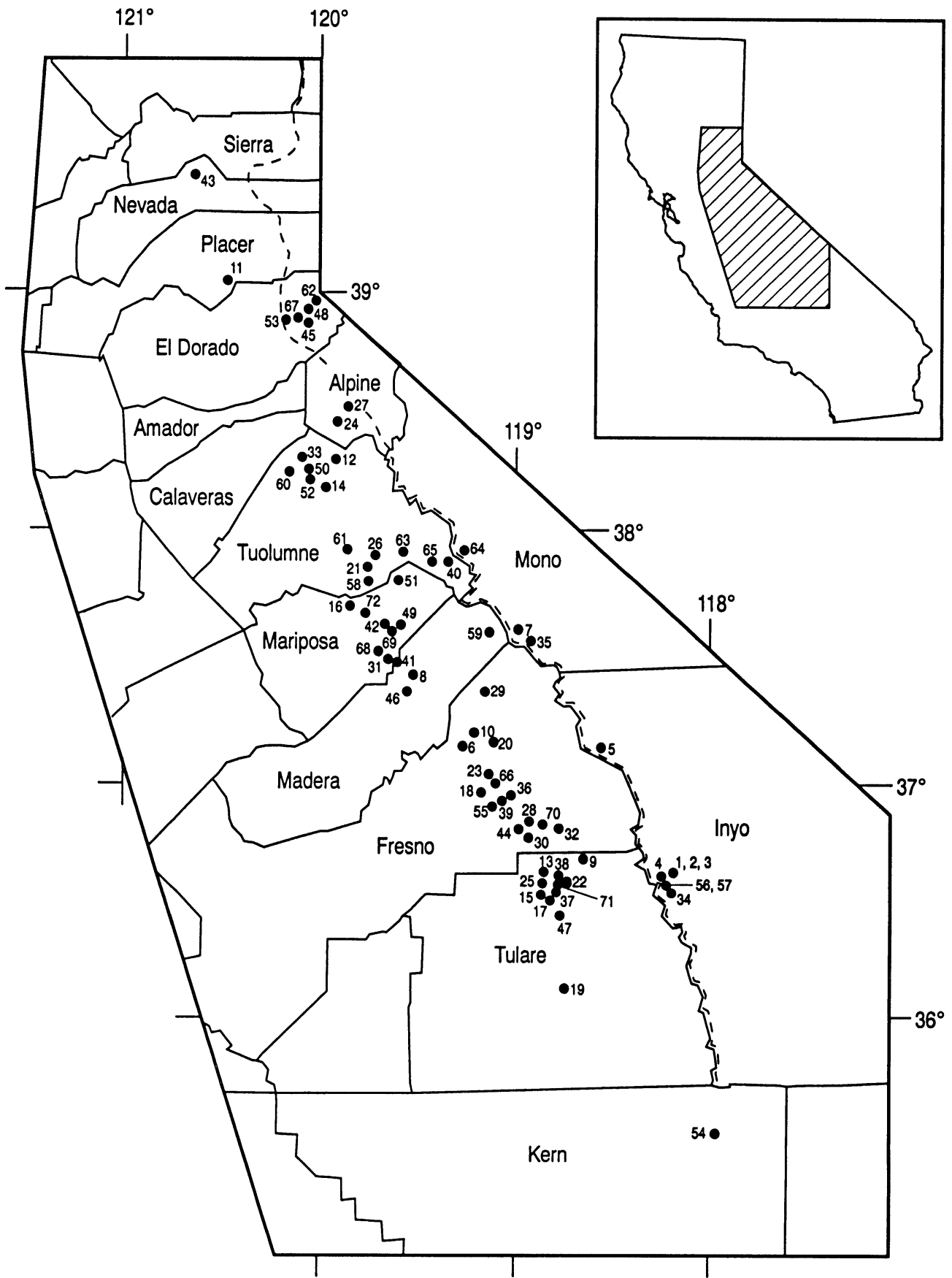

Fig. 1. Location of paleoecological sites within the Sierra Nevada. Numbers are keyed to Appendix. $\cdots=$ the Sierra crest, separating the east from the west sides.

Data were compiled from 72 sites (Appendix), undoubtedly making the Sierra Nevada one of the most heavily studied regions in western North America. A total of $234{ }^{14} \mathrm{C}$ dates for the 72 sites have been obtained. The number of dates per record ranges from 1 ( 25 sites) to 12 (1 site) (Fig. 2). 


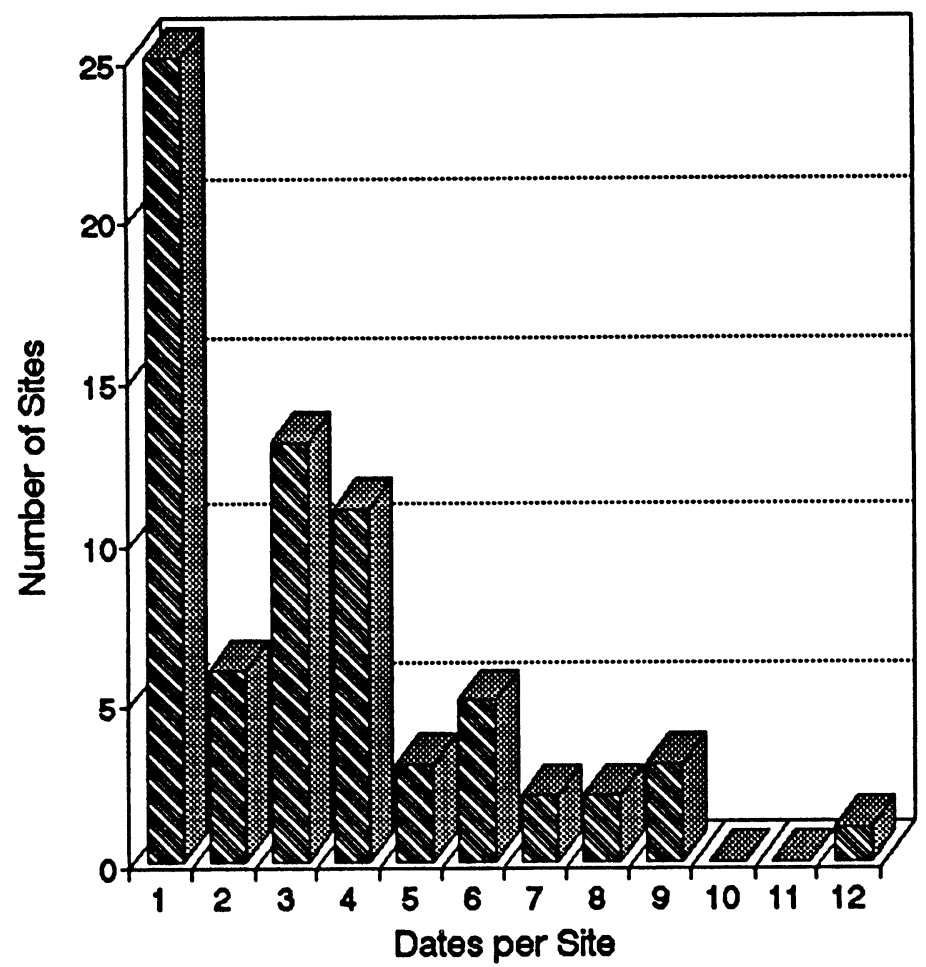

Fig. 2. Distribution of the number of sites with a given number of dates

\section{Location of Sites}

Most of the lands in the central Sierra Nevada are administered by the federal government or other governmental agencies (SNEP Science Team 1996). The locations of many paleoecological sites were chosen in order to answer questions pertaining to management of forests under government stewardship. Forty studies were conducted on lands administered by the U.S. Forest Service, and an additional 28 studies within U.S. National Parks. Portions of the Sierra Nevada lie within ca. $20 \mathrm{Cal}$ ifornia counties. However, the 72 locations enumerated here occur largely within 10 counties in the central and southern Sierra (Appendix), while two sites occur in the northern Sierra.

\section{Published vs. Unpublished Records}

Adam (1985) pointed out that records of many of the California sites were unpublished. Data reported here show that trend has been reversed (Appendix). Only $41 \%$ of the sites have not been published (we include here M.S. and Ph.D. theses in this category). The number of published ${ }^{14} \mathrm{C}$ dates exceeds unpublished (183 vs. 51).

\section{Distribution by Sediment Type}

Several sediment types are available for paleoecological study in the Sierra Nevada. Analysis of cores or sections from montane meadows comprise $51 \%$ (37) of the studies conducted to date (Table 1). Thirty-three percent (24) of studies are from lakes, followed by $7 \%$ each (5) for packrat middens and marshes. However, packrat midden studies include a larger average number of individual dates per study (6.2), compared to lake (3.1), meadow (3.1) and marsh (2.5) studies. This is because each midden must be individually ${ }^{14} \mathrm{C}$-dated, while fewer dates are generally necessary to establish a stratigraphic chronology. 
The majority of dates obtained from meadows are of bulk colluvial/alluvial sediments, though wood samples have been used extensively for establishing sediment chronologies (Table 1). For packrat middens, fecal pellets and amberat (crystallized rat urine, which cements most middens) have been the preferred materials for dating.

\begin{tabular}{|c|c|c|c|}
\hline Sediment type & $\begin{array}{c}\text { No. } \\
\text { of dates }\end{array}$ & $\begin{array}{l}\text { Total } \\
\text { dates }\end{array}$ & $\begin{array}{c}\text { No. } \\
\text { of sites }\end{array}$ \\
\hline Marsh & & 11 & 5 \\
\hline Peat & 9 & & \\
\hline Wood & 1 & & \\
\hline Lake & 1 & & \\
\hline Meadow & & 116 & 37 \\
\hline Charcoal & 9 & & \\
\hline Peat & 11 & & \\
\hline Wood & 24 & & \\
\hline Colluvial; alluvial & 72 & & \\
\hline Midden & & 31 & 5 \\
\hline Fecal/amberat & 27 & & \\
\hline Plant material & 4 & & \\
\hline Lake & & 75 & 24 \\
\hline Archaeological & 1 & 1 & 1 \\
\hline Total & & 234 & 72 \\
\hline
\end{tabular}

\section{Age Distribution}

Figure 3 shows bar graphs of age distribution of ${ }^{14} \mathrm{C}$ dates and calibrated ages by 1000 -yr intervals. Calibration of ${ }^{14} \mathrm{C}$ ages from the present to 19,262 BP was performed using the CALIB 3.0 program of Stuiver and Reimer (1993). From 19,262 to 27,120 BP, we linearly interpolated between equivalent ${ }^{14} \mathrm{C}$ and U-Th ages given by Bard et al. (1990). From 27,120 to 50,000 BP, we used the relationship suggested by Mazaud et al. (1991) and Thouveny, Creer and Williamson (1993).

A bimodal distribution of ages is apparent, centered around 1000-4000 BP and 10,000-12,000 BP. The number of dates older than $c a .12,000 \mathrm{BP}$ declines toward zero, with the oldest date recorded at $>45,000$ BP (Kings Canyon midden series). All of the dates older than 20,000 BP are from packrat midden series, whereas the oldest date from a stratigraphic sequence is $c a .17,000 \mathrm{BP}$. Thus, Holocene events are well represented paleoecologically, while the Pleistocene of the Sierra is much less well known.

In their analysis of 1113 packrat midden dates, Webb and Betancourt (1990) noted a similar bimodal distribution of ${ }^{14} \mathrm{C}$ dates, with maximum number of dates in the time ranges of $0-3000$ and $c a$. $10,000-12,000{ }^{14} \mathrm{C}$ yr ago. They compared their histogram distribution with a gamma probability distribution, which largely describes frequency distributions with an apparent exponential decay. An ideal gamma distribution shows a greater number of ${ }^{14} \mathrm{C}$ dates for the youngest portion of the timescale, with an exponential decay (fewer dates) with increasing age. Webb and Betancourt's (1990) bimodal distribution was explained by a combination of researcher bias and decreased preservation potential with increasing age. Early in the development of midden analysis, middens with extralocal plant fossils were preferentially selected for analysis and dating. This created a large number of middens of latest Pleistocene age. Only later were Holocene-age middens collected and analyzed. Thus, the midden record represents two different populations-one Pleistocene and one Holocene ( $O$. Davis, personal communication 1997). 

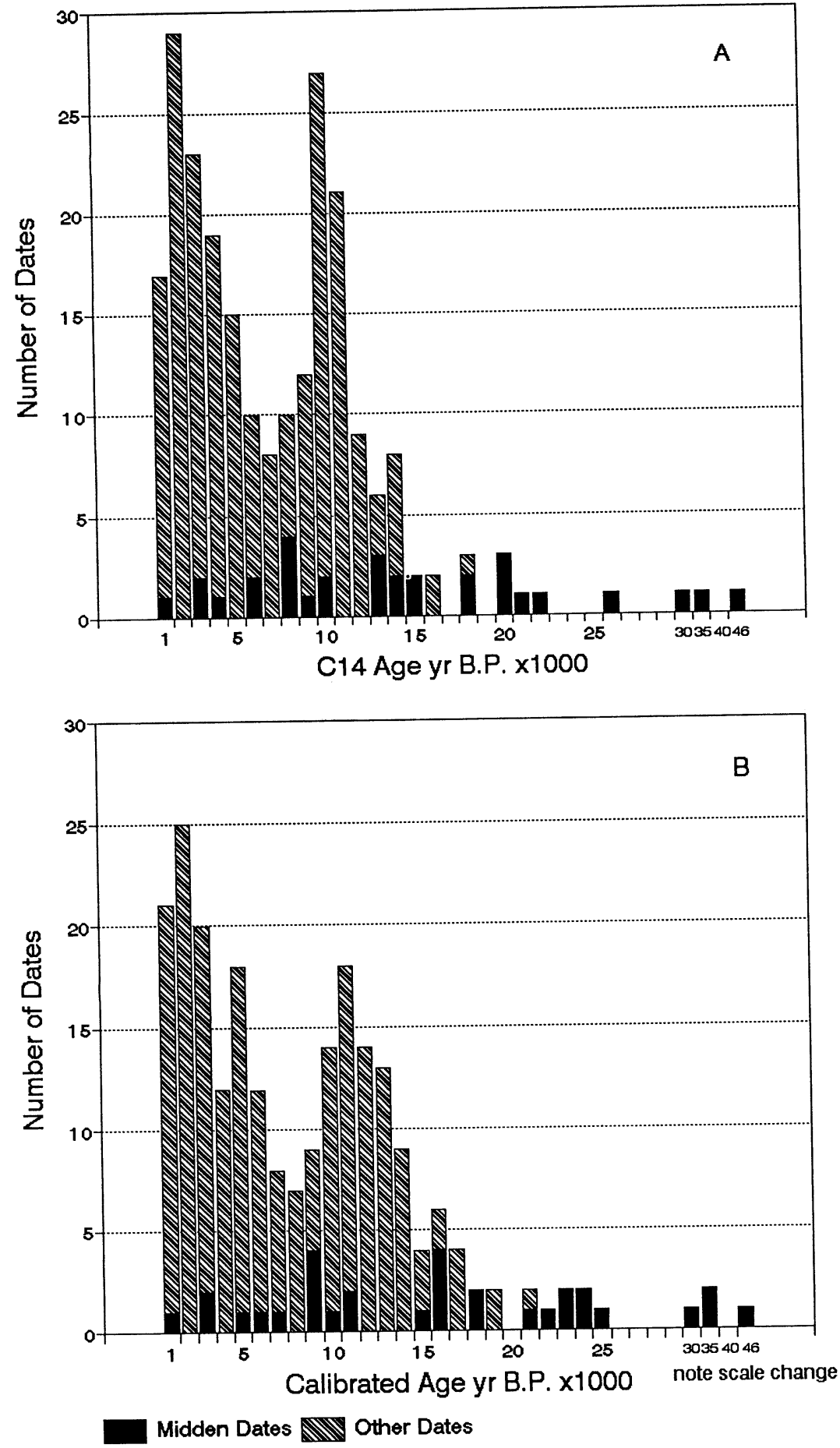

Fig. 3. Distribution of individual ${ }^{14} \mathrm{C}$ dates by 1000 -yr intervals. A. Ages listed in ${ }^{14} \mathrm{C}$ yr BP; B. Ages listed in calendar years before present. Note scale change at the right of each diagram. 
Graphically, the patterns identified in the Webb and Betancourt (1990) study and the present one (Fig. 3) are similar, but the explanations are different. Though fewer midden dates were collected in the present study than in Webb and Betancourt's study, temporal distribution of midden dates is approximately uniform through time (Fig. 3, black bars), minimizing the importance of collector bias or changing environmental conditions as explanations for the Sierran midden record. Stratigraphic dates account for most of the patterns seen in Figure 3. Because most of the dates come from continuous sections (Table 1), any level within the section could have been chosen for dating by the individual investigator. The peak in ${ }^{14} \mathrm{C}$ ages from $\mathrm{ca}$. 9000 to $11,000 \mathrm{BP}$ (Fig. 3A; somewhat smoothed out in the calibrated ages curve, Fig. 3B) results from dating of basal sediments. Thirtyseven percent (21) of the 57 records with basal dates occur within this 2000 -yr interval (Fig. 4). Furthermore, $54 \%$ of basal dates occur between 8000 and 12,000 yr BP, suggesting that the majority of stratigraphic records in the Sierra extend back only to the early Holocene or latest Pleistocene.

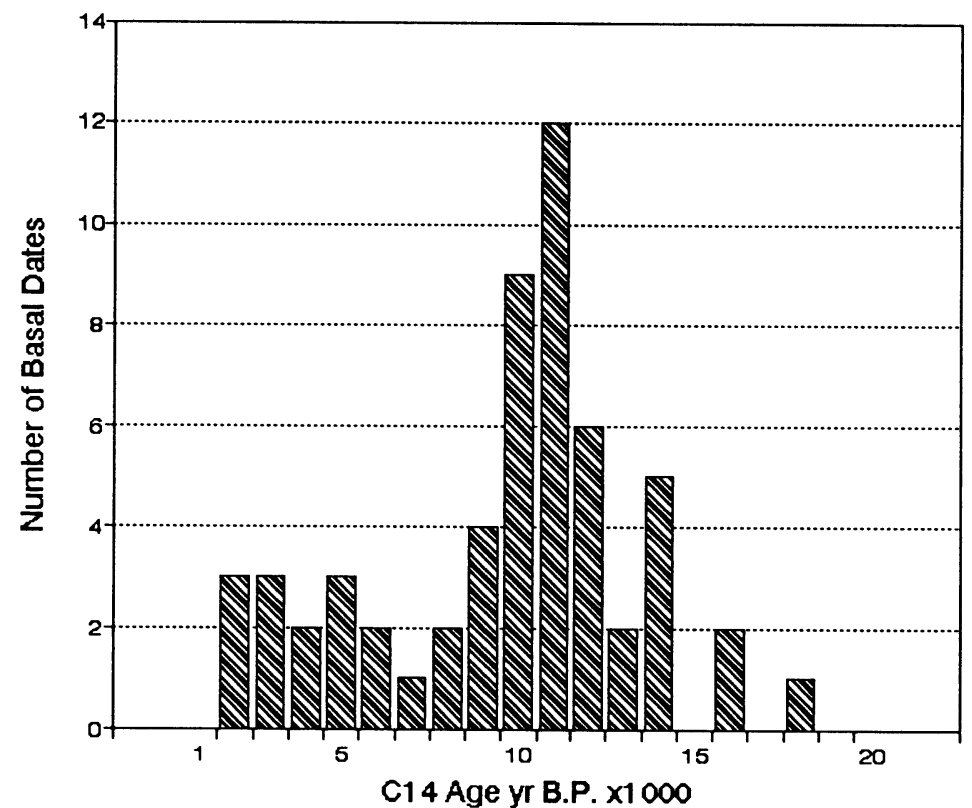

Fig. 4. Distribution of age of basal ${ }^{14} \mathrm{C}$ dates by 1000 -yr intervals for stratigraphic records

The abundance of dates between 1000 and $4000 \mathrm{BP}$ almost certainly correlates with an important paleoecological change in the sedimentary column. Using pollen and sedimentary changes, Anderson and Smith (1994) showed widespread, late Holocene changes, and suggested a probable connection with the onset of the Neoglacial interval (Burke and Birkeland 1983). An alternative explanation suggests the "pull of the recent", with a greater likelihood of preservation of younger records than older ones. This explanation cannot account for all of the distribution, since $56 \%$ of sites with one or more dates in the 1000 to 4000 -yr range also have basal dates of $c a .8000 \mathrm{yr}$ or older. The patterns exhibited in Figure 3 are clearly nonrandom.

\section{Distribution of Sites by Elevation and Latitude}

Figures 5 and 6 depict plots of location of sites and ages of ${ }^{14} \mathrm{C}$ samples (and by inference the location of sites in space and time) for both the east and west sides of the Sierran crest. Far fewer paleoecological sites with associated ${ }^{14} \mathrm{C}$ dates have been analyzed on the east side of the crest (17 sites and 53 ages) than on the west side (55 and 179). 

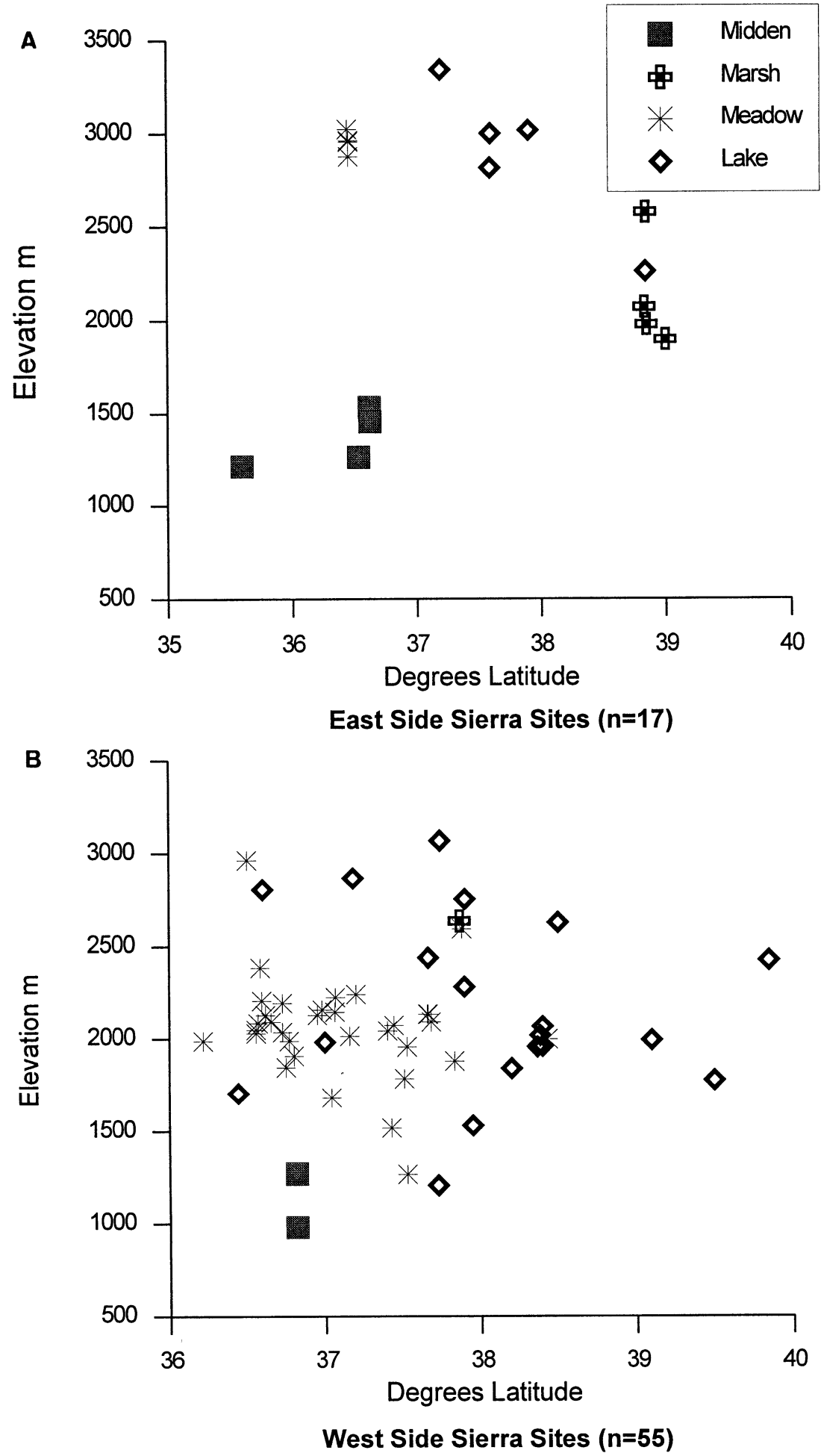

Fig. 5. Distribution of ${ }^{14} \mathrm{C}$ dates by elevation and latitude for the east side (A) and west side (B) of the Sierra crest. Sediment type is also indicated by symbols in legend. 

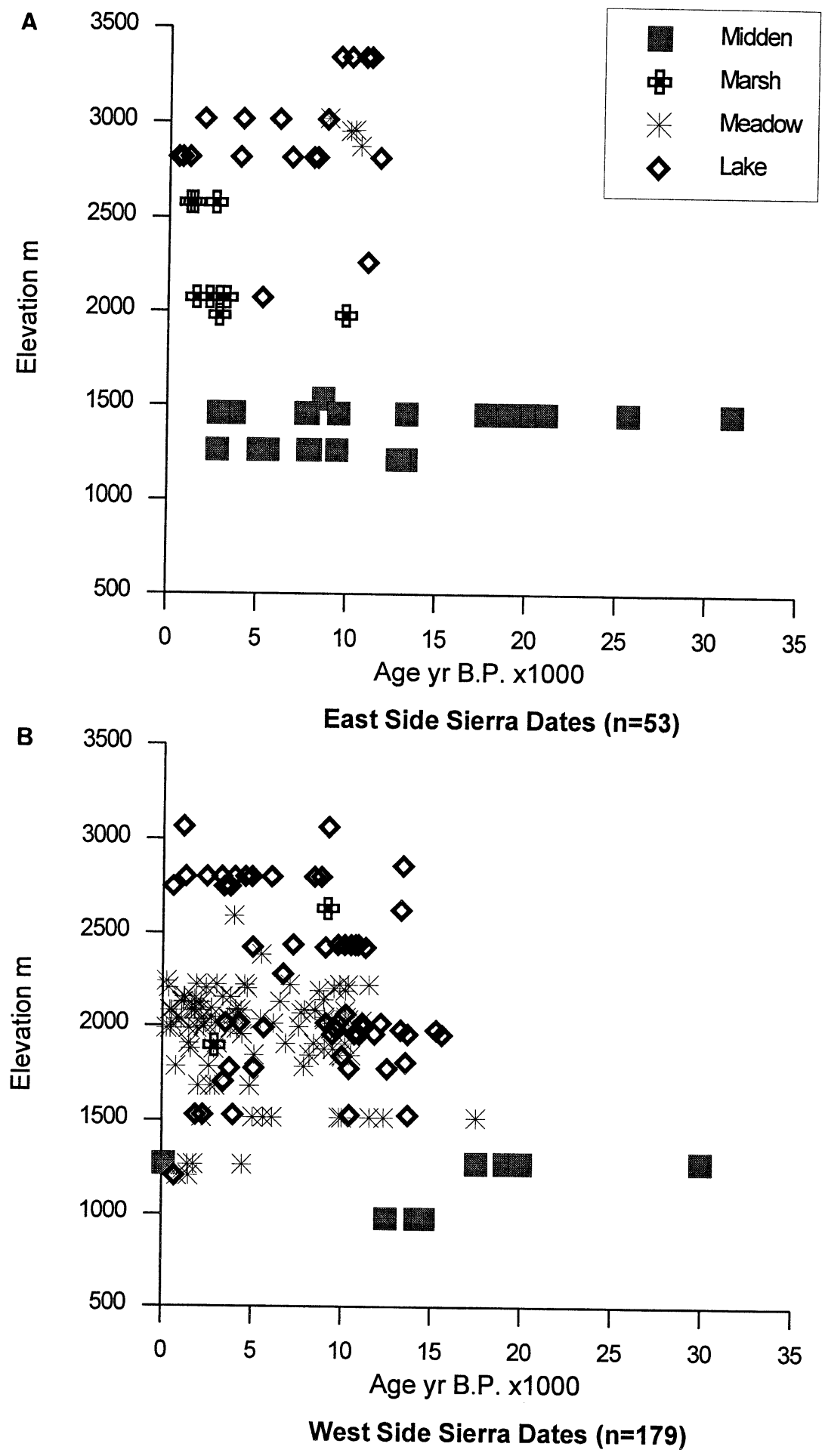

Fig. 6. Distribution of ${ }^{14} \mathrm{C}$ dates by elevation and age for the east side (A) and west side (B) of the Sierra crest. Sediment type is also indicated by symbols in the legend. 
Several factors account for this. First, the east side of the Sierra lies in a rain shadow. For any given elevation, the greater aridity of the east side results in fewer sites with wet sediment accumulation. Second, the Sierra Nevada consists of a gently sloping west slope, and a much steeper east slope that is less areally extensive. Third, because of the steepness of the east side, glaciation was confined largely to high-elevation plateaus and to major drainages, and less so to interfluves. On the west side of the crest, however, the more gently sloping topography and greater ice accumulation enabled glacial activity to produce many basins (Huber 1987).

\section{Sites East of the Crest}

Seventeen sites record paleoecological changes east of the crest (Fig. 5). However, sites are not distributed uniformly with respect to elevation. Sites are segregated into packrat midden series below $1460 \mathrm{~m}$ elevation, and stratigraphic deposits above $1888 \mathrm{~m}$ elevation. For the latter, marsh deposits occur from ca. $1888 \mathrm{~m}$ (Taylor Marsh) to ca. $2580 \mathrm{~m}$ elevation (Ralston Ridge Bog). With two exceptions, analysis of lake and meadow deposits has been confined to locations above $2816 \mathrm{~m}$ elevation.

The latitudinal distribution of sites is not uniform either (Fig. 5). For the east side, the three packrat midden sites (all at lowest elevations) are located at the southern end of the study area. The high-elevation meadow sites are also located toward the south, while most high-elevation lake sites are found within the northcentral part of the study area. However, the mid-elevation records between $c a$. 1900 and $2600 \mathrm{~m}$ elevation occur only in the northern portion, near Lake Tahoe.

\section{Sites West of the Crest}

Fifty-five sites on the west side of the crest (Fig. 5) provide somewhat greater resolution of the paleoecology of the range than that provided on the east side. As on the east side, sites are segregated by elevation with respect to sediment type, but to a lesser degree. Packrat midden series are confined to the lowest elevations, below $1275 \mathrm{~m}$. Primarily lake sites have been analyzed above $2740 \mathrm{~m}$. At mid-elevations, both meadow and lakes have been investigated.

The latitudinal distribution of sites with respect to elevation on the west side of the Sierra reflects a different pattern than on the east. Western Sierra sites occur over a narrower range in latitude, primarily between $\mathrm{ca} .36^{\circ}$ and $38^{\circ} 30^{\prime} \mathrm{N}$ (Fig. 5); three outliers, Siesta, McMurray and Bunker Lakes, occur north of $39^{\circ} \mathrm{N}$. In the southern portion of the study area meadow sites predominate, especially at locations between $1500 \mathrm{~m}$ and $2220 \mathrm{~m}$; lake sites are rare within this elevational range. However, lakes in general become increasingly more abundant toward the north. Consequently, more lakes than meadows have been analyzed toward the north (Fig. 5). Lake sites are primarily distributed around $38^{\circ} \mathrm{N}$ latitude, in and near Yosemite National Park. Exceptions to this include Emerald Lake $(2804 \mathrm{~m})$ and Oriole Lake $(1697 \mathrm{~m})$, both located in Sequoia National Park in the south.

Though limited latitudinally, lake sites have been analyzed from nearly the entire elevational range. Meadow sites, virtually all to the south of $38^{\circ} \mathrm{N}$, are concentrated over a somewhat narrower range of elevations than the lakes. The lowest-elevation meadow sites analyzed on the west side (Wawona and Nichols Meadows) are found in the central portion of the study area. In general, the lowest elevation of stratigraphic paleoecological sites increases from north to south on the west side. This may reflect a decrease in effective precipitation from north to south for any given elevation (Major 1988), and the resulting potential for accumulation of wet sediment. 


\section{IDENTIFYING GAPS IN PALEOECOLOGICAL KNOWLEDGE}

The data are useful in identifying gaps in our knowledge of events in time and space for the Sierra Nevada. At present, many more gaps in the record exist for the east side than for the west side of the crest.

For the east side, the mid-Wisconsin period is known only from the Alabama Hills Two Goblin site, in the south (Fig. 6). No site older than ca. 11,500 BP is found above $1460 \mathrm{~m}$ elevation. Similarly, large gaps exist in the elevational ranges of $c a .1500-2000 \mathrm{~m}(4900-6600 \mathrm{ft})$ and $c a .2100-2600 \mathrm{~m}$ $(6900-8500 \mathrm{ft})$. These elevations presently encompass the sagebrush and lodgepole-fir belts in the north, and the sagebrush and pinyon pine belts in the south. In addition, sites above modern treeline have not been analyzed. Low-, and additional high-, elevation sites need to be analyzed in the northern portion of the study area, while mid-elevations in the central and southern portions lack data.

On the west side, the mid-Wisconsin is known only from one low-elevation site in the south-two middens from Kings Canyon (1280 m; Fig. 6). Unlike the east side, five sites above $1500 \mathrm{~m}$ elevation stretch back to ca. 15,000-17,000 BP (Nichols Meadow, $1518 \mathrm{~m}$; Swamp Lake Yosemite, 1554 m; Swamp Lake Batchelder, $1951 \mathrm{~m}$; Lilypad Lake, $1980 \mathrm{~m}$; and Lake Moran, $2020 \mathrm{~m}$ ). While Nichols Meadow was apparently below the Tioga glacial limit (Alpha, Wahrhaftig and Huber 1987), the latter four sites come from glaciated terrain, and suggest early deglaciation at these elevations. Additional temporal gaps include most of the Holocene and late Pleistocene for locations below $c a$. $1500 \mathrm{~m}(4900 \mathrm{ft})$. These elevations today include the lower portion of the Sierra montane forest (including the ponderosa pine belt), the chaparral, blue oak-gray pine woodland and the valley prairie ecozones. Little information exists for $c a .1550-1750 \mathrm{~m}(5100-5700 \mathrm{ft})$ for the early Holocene, and $c a .2300-2700$ (7550-8900 ft) elevation for the late Holocene. Vegetation occurring there today is part of the Sierra montane and upper montane forests, respectively. As with the east side, no sites above treeline have been analyzed. Latitudinally, information is limited north of $c a .38^{\circ} 30^{\prime} \mathrm{N}$ and south of $36^{\circ} \mathrm{N}$ latitudes.

\section{ConClusion}

David Adam's (1985) compilation of paleoecological sites within California provided palynologists working in western North America with a tool useful for planning future research. Adam identified significant holes in our knowledge of late Quaternary environments of California. One range in particular, the Sierra Nevada, has attracted several researchers. Though the Sierra still contains geographic and temporal gaps in our paleoenvironmental knowledge, the present compilation demonstrates that those gaps have narrowed significantly.

With respect to the latitudinal distribution of sites, our knowledge of the northern Sierra is less than that of the central or southern portions of the range. Northern Sierra vegetation has greater affinities to that of the Great Basin and the Cascade Range than does vegetation in the south. Additional study here could provide needed insight into the biogeographic connections between the more northerly regions.

Additional studies should be undertaken on the east side of the crest to partially fill gaps in our knowledge of elevational vegetation change. High-elevation studies are few in the north, and midelevation studies in the south are completely lacking. Though the steep escarpment there may preclude finding suitable sites, such a study in the south could illuminate the location of high-elevation conifers during the late Wisconsin in the Sierra. The midden series from the Alabama Hills (Koehler 
and Anderson 1995) is apparently from too low an elevation to record the occurrence of important Sierran trees during that time.

No study has been conducted at sites above modern treeline. Such an effort could illuminate potentially higher treelines during the early Holocene, when climatic conditions were at their warmest and driest (Anderson 1990, 1996). These new studies may also be important in evaluating use of the early Holocene as an analog for future greenhouse warming.

Though study of sediments from pluvial lakes (e.g., Atwater et al. 1986; Litwin et al. 1997) reveals vegetation changes at the lowest elevations on both sides of the crest, efforts should be continued to identify additional packrat midden series. For instance, Cole (1983) documented the Wisconsin-age occurrence of important Sierra montane species, such as ponderosa pine, in modern chaparral, and suggested that giant sequoia (Sequoiadendron giganteum) may have grown nearby as much as 500 $\mathrm{m}$ below its modern distribution. Additional series further to the north are necessary to identify other Wisconsin-age refugia, and to complete the picture of the development of the Sierra montane forest in general.

Within the Sierra, many types of sediments are available to the paleoecologist, and the choice of sediment type depends largely upon elevation. In general, lakes are most abundant above the Sierra montane zone, though several important studies have been conducted from lower-elevation lakes (Fig. 5). Within the Sierra montane zone, where lakes are rare, meadow stratigraphies have been analyzed to a greater extent (Anderson and Smith 1994). At even lower elevations, sedimentary deposits with appropriate preservation potential are rare, and packrat midden studies predominate.

Each sediment type has advantages and disadvantages. Packrat middens often occur at the lower, more arid elevations, where other stratigraphic deposits are not found. However, individual middens represent discrete windows in space and time, and the midden series rarely represent continuous changes in vegetation. Meadow sediments provide a mid-elevation record, yet are subject to periodic desiccation. Drying events, along with periodic fires that burn the meadows, are potential causes of disconformities in the pollen stratigraphy. Lakes are abundant at high elevations, but only rarely occur below the late Wisconsin glacial limit. Using a combination of studies from each elevation allowed Anderson and Smith (1991) and Woolfenden (1996) to summarize the story of vegetation change for the Sierra.

Though many studies have appeared in the literature since 1985 , more than $40 \%$ of the site reports remain unpublished. This is the mark of active research within a region. Further investigation within the range will fill additional gaps in the history of vegetation change, refining our understanding of the development of the rich vegetation assemblages that are characteristic of the Sierra Nevada. It will also undoubtedly provide the starting point for research unanticipated at present.

\section{ACKNOWLEDGMENTS}

This compilation could not have been accomplished without the generous sharing of information among researchers working within the area. We wish to thank Roger Byrne, Margaret Davis, Eric Edlund, Jerry DeGraaf, Lili Mezger, Jim West and Don Whitehead for allowing us to use unpublished information; Pat Bartlein and Cathy Whitlock for suggesting the methodology for calibrating ${ }^{14} \mathrm{C}$ dates; Darden Hood and Lethia Cerdá for their help with the calibrations, and Owen Davis for his thoughtful and thought-provoking comments on the manuscript. This research is supported by NPS Contracts CA 8000-7-0001 and CA 8013-8-0002 to RSA and Yosemite Association grants to SJS and PAK. This is Laboratory of Paleoecology Contribution \# 32. 


\section{REFERENCES}

Adam, D. P. 1967 Late Pleistocene and Recent palynology in the Sierra Nevada, California. In Cushing, E. J. and Wright, H. E., Jr., eds., Quaternary Paleoecology. New Haven, Yale University Press: 275-301.

1985 Quaternary pollen records from California. In Bryant, V. M., Jr. and Holloway, R. G., eds., Pollen Records of Late-Quaternary North American Sediments. Dallas, American Association of Stratigraphic Palynologists: $125-140$.

Alpha, T. R., Wahrhaftig, C. and Huber, N. K. 1987 Oblique map showing maximum extent of 20,000-yearold (Tioga) glaciers, Yosemite National Park, central Sierra Nevada, California. U. S. Geological Survey, Miscellaneous Investigations Series, Map I-1885.

Anderson, R. S. (ms. ) 1987 Late-Quaternary environments of the Sierra Nevada, California. Ph. D. Dissertation, University of Arizona: $290 \mathrm{p}$.

1990 Holocene forest development and paleoclimates within the central Sierra Nevada, California. Journal of Ecology 78: 470-489.

1994 Paleohistory of a giant sequoia grove: The record from Log Meadow, Sequoia National Park. In Aune, P. S. (compiler), Proceedings of the Symposium on Giant Sequoias: Their Place in the Ecosystem and Society. USDA Forest Service, General Technical Report PSW-GTR-151: 49-55.

1996 Postglacial biogeography of Sierra lodgepole pine (Pinus contorta var. murrayana) in California. Ecoscience 3: 343-351.

Anderson, R. S. and Carpenter, S. L. 1991 Vegetation change in Yosemite Valley, Yosemite National Park, California, during the protohistoric period. Madroño 38: 1-13.

Anderson, R. S. and Smith, S. J. 1991 Paleoecology within California's Sierra Nevada National Parks: An overview of the past and prospectus for the future. In Carpenter, S. L., ed., Yosemite Centennial Symposium Proceedings. Denver, National Park Service: 329337.

1994 Paleoclimatic interpretations of meadow sediment and pollen stratigraphies from California. Geology 22: 723-726.

1997 The sedimentary record of fire in montane meadows, Sierra Nevada, California, USA: A preliminary assessment. In Clark, J. S., Cachier, H., Goldammer, J. G. and Stocks, B., eds., Sediment Records of Biomass Burning and Global Change. NATO ASI Series I, Global Environmental Change, no. 51. Berlin, Springer-Verlag: 313-327.

Atwater, B. F., Adam, D. P., Bradbury, J. P., Forester, R. M., Mark, R. K., Lettis, W. R., Fisher, G. R., Gobalet, K. W. and Robinson, S. W. 1986 A fan dam for Tulare Lake, California, and implications for the Wisconsin glacial history of the Sierra Nevada. Geological Society of America Bulletin 97: 97-109.

Baker, R. G. 1983 Holocene vegetational history of the western United States. In Wright, H. E., Jr., ed., LateQuaternary Environments of the United States. Vol. 2. The Holocene. Minneapolis, University of Minnesota Press: 109-127.

Bard, E., Hamelin, B., Fairbanks, R. G. and Zindler, A. 1990 Calibration of the ${ }^{14} \mathrm{C}$ timescale over the past 30,000 years using mass spectrometric U-Th ages from Barbados corals. Nature 345: 405-410.

Barnosky, C. W., Anderson, P. M. and Bartlein, P. J. 1987 The northwestern U. S. during deglaciation; vegetational history and paleoclimatic implications. In Ruddiman, W. F. and Wright, H. E., Jr., eds., North America and Adjacent Oceans During the Last Deglaciation. Boulder, Colorado, Geological Society of America: 289-322.

Batch, J. R. (ms.) 1977 A post-glacial pollen record from a subalpine valley in Yosemite National Park. M.S. Thesis, San Francisco State University: 47 p.

Batchelder, G. L. 1980 A Late Wisconsinan and Early Holocene lacustrine stratigraphy and pollen record from the west slope of the Sierra Nevada, California. American Quaternary Association Abstracts and Program 6: 13.

Betancourt, J. L., Van Devender, T. R. and Martin, P. S. 1990 Packrat Middens: The Last 40,000 Years of Biotic Change. Tucson, University of Arizona Press: $467 \mathrm{p}$.

Brandau, B. L. and Noakes, J. E. 1975 University of Georgia radiocarbon dates IV. Radiocarbon 17(1): 99-111.

Brunelle, A. R. (ms.) 1997 A post-glacial record of fire and vegetation from Siesta Lake, Yosemite National Park, California. M.S. thesis, Northern Arizona University: 74 p.

Burke, R. M. and Birkeland, P. W. 1983 Holocene glaciation in the mountain ranges of the western United States. In Wright, H. E., Jr., ed., Late-Quaternary Environments of the United States. Vol. 2. The Holocene. Minneapolis, University of Minnesota Press: 3-11.

Byrne, R. 1988 Late-Quaternary climate and vegetation change in the central Sierra Nevada of California. Ecological Society of America Abstracts with Program 73: 89.

Cole, K. L. 1983 Late Pleistocene vegetation of Kings Canyon, Sierra Nevada, California. Quaternary Research 19: 117-129.

Davis, O. K., Anderson, R. S., Fall, P. L., O'Rourke, M. K. and Thompson, R. S. 1985 Palynological evidence for early Holocene aridity in the southern Sierra Nevada, California. Quaternary Research 24: 322-332.

Davis, O. K. and Moratto, M. J. 1988 Evidence for a warm dry early Holocene in the western Sierra Nevada of California: Pollen and plant macrofossil analysis of Dinkey and Exchequer Meadows. Madroño 35: 132-149.

Dorland, D. (ms.) 1980 Two post-glacial pollen records 
from Meyers Grade Marsh and Grass Lake, El Dorado County, California. M.S. thesis, San Francisco State University: $103 \mathrm{p}$.

Dorland, D., Adam, D. P. and Batchelder, G. L. 1980 Two Holocene pollen records from Meyers Grade Marsh and Grass Lake, El Dorado County, California. American Quaternary Association Abstracts and Program 6: 64 .

Edlund, E. (ms.) 1991 Reconstruction of late Quaternary vegetation and climate at Lake Moran, central Sierra Nevada, California. M.S. thesis, University of California, Berkeley: $124 \mathrm{p}$.

1992 Responses of California oaks to early Holocene climatic warming. Association of American Geographers Abstracts, Annual Meeting: 63.

1994 Bunker Lake paleoecological analysis. In Jackson, R. J., ed., Framework for Archaeological Research and Management, National Forests of the North-Central Sierra Nevada. U. S. Forest Service, Special Publication, Placerville, California: 1-23.

Edlund, E. and Byrne, R. 1991 Climate, fire, and late Quaternary vegetation change in the central Sierra Nevada. In Fire and the Environment: Ecological and Cultural Perspectives. USDA Forest Service, General Technical Report SE-69: 390-396.

Hemphill, M. and Clark, D. 1996 Evidence for cooling during the Younger Dryas period in the paleoecologic record from Baboon Lake, Upper Bishop Creek, California. American Quaternary Association Abstracts 14: 84.

Huber, N. K. 1987 The Geologic Story of Yosemite National Park. U.S. Geological Survey Bulletin 1595. Washington, D.C., U.S. Geological Survey: 64 p.

Koehler, P. A. (ms.) 1993 The paleoecology and stratigraphy of Nichols Meadow, Sierra National Forest, California. M.S. thesis, Northern Arizona University: $59 \mathrm{p}$.

Koehler, P. A. and Anderson, R. S. 1994 The paleoecology and stratigraphy of Nichols Meadow, Sierra National Forest, California, USA. Palaeogeography, Palaeoclimatology, Palaeoecology 112: 1-17.

1995 Thirty thousand years of vegetation changes in the Alabama Hills, Owens Valley, California. Quaternary Research 43: 238-248.

Litwin, R. J., Adam, D. P., Fredericksen, N. O. and Woolfenden, W. B. 1997 An 800,000-year pollen record from Owens Lake, California: Preliminary analyses. In Smith, G. I and Bischoff, J. L., eds., An 800,000Year Paleoclimatic Record from Core OL-92, Owens Lake, Southeastern California. Geological Society of America Special Publication 317. Boulder, Colorado, GSA: 127-142.

Mackey, E. M. and Sullivan, D. G 1991 Appendix E: Revised final report, results of palynological investigations at Gabbott Meadow Lake, Alpine County, California. In Peak, A. S. and Neuenschwander, N. J., eds., Cultural Resource Studies, North Fork Stanislaus
River Hydroelectric Development Project. Sacramento, Peak and Associates: 473-499.

Major, J. 1988 California climate in relation to vegetation. In Barbour, M. J. and Major, J., eds., Terrestrial Vegetation of California. California Native Plant Society, Special Publication 9. Davis, California, CNPS: 11-74.

Mazaud, A., Laj, C., Bard, E., Arnold, M. and Tric, E. 1991 Geomagnetic field control of ${ }^{14} \mathrm{C}$ production over the last $80 \mathrm{ky}$ : Implications for the radiocarbon time-scale. Geophysical Research Letters 18: 18851888.

McCarten, N. and Van Devender, T. R. 1988 Late Wisconsin vegetation of Robber's Roost in the western Mojave Desert, California. Madroño 35: 226-237.

Mezger, E. B. (ms.) 1986 Pleistocene glaciation of Cottonwood Basin, southeastern Sierra Nevada, California. M.S. thesis, University of Southern California: $149 \mathrm{p}$.

Mitchell, V. 1976 The regionalization of climate in the western United States. Journal of Applied Meteorology 15: 920-927.

Pohl, M. M., Fall, P. L., Arundel, S. L., Brinkman, P. D., Davies, C. P., Douglas, D. L. and Emrick, S. M. 1996 Holocene vegetation and climatic history of Laurel Lakes Canyon, Sierra Nevada, CA. American Quaternary Association Abstracts 14: 18.

Sercelj, A. and Adam, D. P. 1975 A late Holocene pollen diagram from near Lake Tahoe, El Dorado County, California. U.S. Geological Survey, Journal of Research 3: 737-745.

Smith, S. J. (ms.) 1989 Pollen and microscopic charcoal analysis of a sediment core from Swamp Lake, Yosemite National Park, California. M.S. thesis, Northern Arizona University: 85 p.

Smith, S. J. and Anderson, R. S. 1992 Late Wisconsin paleoecologic record from Swamp Lake, Yosemite National Park, California. Quaternary Research 38: 91 102.

SNEP Science Team 1996 Sierra Nevada ecosystems. In Sierra Nevada Ecosystem Project Science Team, eds., Sierra Nevada Ecosystem Project: Final Report to Congress. Vol. 1. Assessment Summaries and Management Strategies. Davis, Centers for Water and Wildland Resources, University of California: 5-16.

Storer, T. I. and Usinger, R. L. 1963 Sierra Nevada Natural History. Berkeley, University of California Press: $374 \mathrm{p}$.

Stuiver, M. and Reimer, P. J. 1993 Extended ${ }^{14} \mathrm{C}$ data base and revised CALIB 3. $0{ }^{14} \mathrm{C}$ age calibration program. In Stuiver, M., Long, A. and Kra, R. S., eds., Calibration 1993. Radiocarbon 35(1): 215-230.

Thouveny, N., Creer, K. M. and Williamson, D. 1993 Geomagnetic moment variations in the last 70,000 years, impact on production of cosmogenic isotopes. Global and Planetary Change 7: 157-172.

Webb, R. H. and Betancourt, J. L. 1990 The spatial and 
temporal distribution of radiocarbon ages from packrat middens. In Betancourt, J. L., Van Devender, T. R. and Martin, P. S., eds., Packrat Middens: The Last 40,000 Years of Biotic Change. Tucson, University of Arizona Press: 85-103.

Wood, S. H. 1975 Holocene stratigraphy and chronology of mountain meadows, Sierra Nevada, California. U.S. Department of Agriculture Forest Service Monograph 4: $180 \mathrm{p}$.

Woolfenden, W. B. 1996 Quaternary vegetation history.
In Sierra Nevada Ecosystem Project Science Team, eds., Sierra Nevada Ecosystem Project: Final Report to Congress. Vol. 2. Assessments and Scientific Basis for Management Options. Davis, Centers for Water and Wildland Resources, University of California: 47-90.

Zauderer, J. N. 1973 (ms.) A Neoglacial pollen record from Osgood Swamp, California. M.S. thesis, University of Arizona: $48 \mathrm{p}$.

\section{APPENDIX: LOCATION OF PALEOECOLOGICAL SITES AND ${ }^{14} \mathrm{C}$ DATES WITHIN THE SIERRA NEVADA}

\begin{tabular}{|c|c|c|c|c|c|c|c|}
\hline & \multirow[b]{2}{*}{ Site } & \multirow[b]{2}{*}{ County } & \multicolumn{2}{|c|}{ Elevation } & \multirow[b]{2}{*}{ Sediment type } & \multirow{2}{*}{$\begin{array}{l}\text { No. } \\
\text { dates }\end{array}$} & \multirow[b]{2}{*}{ References } \\
\hline & & & feet & $\mathrm{m}$ & & & \\
\hline 1 & Alabama Hills, Corsair & Inyo & 5035 & 1535 & Midden/fecal pellets & 1 & Koehler \& Anderson 1995 \\
\hline 2 & $\begin{array}{l}\text { Alabama Hills, Lubkin } \\
\text { Cyn. }\end{array}$ & Inyo & 4146 & 1264 & Midden/fecal pellets & 6 & Koehler \& Anderson 1995 \\
\hline 3 & $\begin{array}{l}\text { Alabama Hills, Two } \\
\text { Goblin }\end{array}$ & Inyo & 4780 & 1457 & Midden/fecal pellets & 12 & Koehler \& Anderson 1995 \\
\hline 4 & Atchoo Meadow & Inyo & 9700 & 2957 & Peat & 1 & Mezger 1986, unpubl. \\
\hline 5 & Baboon Lakes & Inyo & 10,976 & 3346 & Lake sediment & 4 & Hemphill \& Clark 1996 \\
\hline 6 & Balsam Meadow & Fresno & 6610 & 2015 & Meadow sediment & 6 & Davis et al. 1985 \\
\hline 7 & Barrett Lake & Mono & 9240 & 2816 & Lake sediment & 8 & Anderson 1990 \\
\hline 8 & Beasore Meadow & Madera & 6800 & 2073 & Wood (fir) & 1 & $\begin{array}{l}\text { Brandau \& Nokes 1975; } \\
\text { Wood } 1975\end{array}$ \\
\hline 9 & Boggy Meadow & Tulare & 7200 & 2195 & Wood (softwood) & 2 & $\begin{array}{l}\text { Brandau \& Nokes 1975; } \\
\text { Wood } 1975\end{array}$ \\
\hline 10 & Boneyard Meadow & Fresno & 7350 & 2240 & Wood & 2 & DeGraaf, unpubl. \\
\hline 11 & Bunker Lake & Placer & 6540 & 1993 & Lake sediment & 3 & Edlund 1994 \\
\hline 12 & Burgson Lake & Tuolumne & 6430 & 1960 & Lake sediment & 3 & Byrne, unpubl. \\
\hline 13 & Cabin Creek Meadow & Tulare & 6860 & 2091 & Meadow sediment & 1 & Anderson, unpubl. \\
\hline 14 & Catfish Lake & Tuolumne & 6040 & 1841 & Lake sediment & 1 & Byrne, unpubl. \\
\hline 15 & Circle Meadow & Tulare & 6840 & 2085 & Meadow sediment & 8 & $\begin{array}{l}\text { Anderson 1996; Anderson } \\
\text { \& Smith 1994; Anderson } \\
\text { \& Smith } 1997\end{array}$ \\
\hline 16 & Crane Flat & Mariposa & 6180 & 1884 & Archaeol. midden & 1 & Adam 1967 \\
\hline 17 & Crescent Meadow & Tulare & 6660 & 2030 & Peat & 1 & Anderson, unpubl. \\
\hline 18 & Dinkey Meadow & Fresno & 5520 & 1682 & Meadow sediment & 4 & Davis \& Moratto 1988 \\
\hline 19 & Dogwood Meadow & Tulare & 6520 & 1987 & Meadow sediment & 4 & $\begin{array}{l}\text { Anderson 1996; Anderson } \\
\text { \& Smith 1994; Anderson } \\
\text { \& Smith } 1997\end{array}$ \\
\hline 20 & East Lake & Fresno & 9395 & 2864 & Lake sediment & 1 & Power, unpubl. \\
\hline 21 & $\begin{array}{l}\text { East Meadow, Aspen } \\
\text { Valley }\end{array}$ & Tuolumne & 6170 & 1881 & Charcoal & 4 & Wood 1975 \\
\hline 22 & Emerald Lake & Tulare & 9200 & 2804 & Lake sediment & 9 & Whitehead, unpubl. \\
\hline 23 & Exchequer Meadow & Fresno & 7300 & 2225 & Colluvium & 7 & $\begin{array}{l}\text { Brandau \& Noakes 1975; } \\
\text { Davis \& Moratto 1988; } \\
\text { Wood } 1975\end{array}$ \\
\hline 24 & Gabbott Megadow & Alpine & 6550 & 1996 & Colluvium & 4 & $\begin{array}{l}\text { Mackey \& Sullivan, un- } \\
\text { publ.; Mackey \& Sullivan } \\
1991\end{array}$ \\
\hline
\end{tabular}




\begin{tabular}{|c|c|c|c|c|c|c|}
\hline \multirow[b]{2}{*}{ Site } & \multirow[b]{2}{*}{ County } & \multicolumn{2}{|c|}{ Elevation } & \multirow[b]{2}{*}{ Sediment type } & \multirow{2}{*}{$\begin{array}{c}\text { No. } \\
\text { dates }\end{array}$} & \multirow[b]{2}{*}{ References } \\
\hline & & feet & $\mathrm{m}$ & & & \\
\hline 25 Halstead Meadow & Tulare & 6980 & 2128 & Meadow sediment & 1 & Anderson, unpubl. \\
\hline 26 Harden Lake & Tuolumne & 7484 & 2281 & Lake sediment & 1 & Batchelder, unpubl. \\
\hline 27 Highland Lake & Alpine & 8614 & 2626 & Lake sediment & 1 & Byrne, unpubl. \\
\hline 28 Hightop Meadow & Fresno & 6260 & 1908 & Meadow sediment & 5 & $\begin{array}{l}\text { Anderson 1996; Anderson } \\
\text { \& Smith 1994; Anderson } \\
\text { \& Smith } 1997\end{array}$ \\
\hline 29 Hoffman Meadow & Fresno & 6700 & 2042 & Conifer cone & 2 & DeGraaf, unpubl. \\
\hline 30 Huckleberry Meadow & Fresno & 6520 & 1987 & Peat & 6 & Anderson \& Smith 1997 \\
\hline 31 J.B. Swale & Mariposa & 5860 & 1786 & Meadow sediment & 3 & $\begin{array}{l}\text { Anderson, unpubl.; Ander- } \\
\text { son \& Smith } 1997\end{array}$ \\
\hline 32 Kings Canyon & Fresno & 4165 & 1269 & Midden & 9 & Cole 1983 \\
\hline 33 Lake Moran & Tuolumne & 6620 & 2018 & Lake sediment & 6 & $\begin{array}{l}\text { Byrne 1988; Edlund 1991, } \\
\text { unpubl.; Edlund \& Byrne } \\
1991\end{array}$ \\
\hline 34 Last Chance Meadow & Inyo & 9720 & 2963 & Peat & 1 & Mezger 1986, unpubl. \\
\hline 35 Laurel Lakes (Lower) & Mono & 9840 & 3000 & Lake sediment & 0 & Pohl et al. 1996 \\
\hline 36 Lily Pad Lake & Fresno & 6500 & 1981 & Lake sediment & 3 & Edlund 1992 \\
\hline 37 Log Meadow & Tulare & 6720 & 2048 & Meadow sediment & 4 & Anderson 1994 \\
\hline 38 Long Creek Meadow & Fresno & 7080 & 2158 & Wood (fir) & 4 & $\begin{array}{l}\text { Brandau \& Nokes 1975; } \\
\text { Wood } 1975\end{array}$ \\
\hline 39 Long Meadow & Tulare & 7240 & 2207 & Meadow sediment & 4 & $\begin{array}{l}\text { Anderson 1996; Anderson } \\
\text { \& Smith 1994; Anderson } \\
\text { \& Smith } 1997\end{array}$ \\
\hline 40 Lower Gaylor Lake & Tuolumne & 10,060 & 3066 & Lake sediment & 2 & Anderson, unpubl. \\
\hline 41 Mariposa Grove & Mariposa & 6420 & 1957 & Colluvium; alluvium & 1 & Anderson, unpubl. \\
\hline 42 McGurk Meadow & Mariposa & 6860 & 2091 & Meadow sediment & 3 & $\begin{array}{l}\text { Anderson 1996; Anderson } \\
\text { \& Smith } 1994\end{array}$ \\
\hline 43 McMurray Lake & Nevada & 5832 & 1778 & Lake sediment & 4 & Edlund 1992 \\
\hline 44 Meadow of Honor & Fresno & 6060 & 1847 & Meadow sediment & 4 & $\begin{array}{l}\text { Anderson 1996; Anderson } \\
\text { \& Smith } 1994\end{array}$ \\
\hline 45 Meyers Grade Marsh & El Dorado & 6800 & 2073 & Peat & 5 & $\begin{array}{l}\text { Dorland 1980, unpubl.; } \\
\text { Dorland, Adam and } \\
\text { Batchelder } 1980\end{array}$ \\
\hline 46 Nichols Meadow & Madera & 4980 & 1518 & Wood & 9 & $\begin{array}{l}\text { Koehler and Anderson } \\
\text { 1994; DeGraaf unpubl., } \\
\text { Swetnam, unpubl.; Koe- } \\
\text { hler } 1993 \text { unpubl. }\end{array}$ \\
\hline 47 Oriole Lake & Tulare & 5600 & 1707 & Lake sediment & 1 & M.B. Davis, unpubl. \\
\hline 48 Osgood Swamp & El Dorado & 6495 & 1980 & Peat & 2 & $\begin{array}{l}\text { Adam 1967; Zauderer } \\
1973 \text { unpubl. }\end{array}$ \\
\hline 49 Ostrander Meadow & Mariposa & 7000 & 2134 & Meadow sediment & 1 & Anderson, unpubl. \\
\hline 50 Paradise Lake & Tuolumne & 5940 & 1811 & Lake sediment & 1 & Byrne, unpubl. \\
\hline 51 Polly Dome Lake & Mariposa & 8640 & 2633 & Marsh & 1 & Batch 1977, unpubl. \\
\hline 52 Pond 3 & Tuolumne & 6780 & 2067 & Lake sediment & 1 & Byrne, unpubl. \\
\hline 53 Ralston Ridge Bog & El Dorado & 8460 & 2579 & Roots & 3 & Sercelj \& Adam 1975 \\
\hline 54 Robbers Roost & Kern & 3985 & 1215 & Midden & 3 & $\begin{array}{l}\text { McCarten \& Van Devender } \\
1988\end{array}$ \\
\hline 55 Ross Meadow & Fresno & 6980 & 2128 & Wood & 2 & DeGraaf, unpubl. \\
\hline 56 Round Valley Meadow & Inyo & 9920 & 3024 & Peat & 1 & Mezger 1986, unpubl. \\
\hline
\end{tabular}




\begin{tabular}{|c|c|c|c|c|c|c|c|}
\hline \multirow{2}{*}{\multicolumn{2}{|c|}{ Site }} & \multirow[b]{2}{*}{ County } & \multicolumn{2}{|c|}{ Elevation } & \multirow[b]{2}{*}{ Sediment type } & \multirow{2}{*}{$\begin{array}{l}\text { No. } \\
\text { dates }\end{array}$} & \multirow[b]{2}{*}{ References } \\
\hline & & & feet & $\mathrm{m}$ & & & \\
\hline & $\begin{array}{l}\text { Second Chance } \\
\text { Meadow }\end{array}$ & Inyo & 9440 & 2877 & Peat & 1 & Mezger 1986, unpubl. \\
\hline 58 & Siesta Lake & Tuolumne & 7950 & 2423 & Lake sediment & 3 & Brunelle 1997, unpubl. \\
\hline 59 & Starkweather Pond & Madera & 8000 & 2438 & Lake sediment & 6 & Anderson 1990 \\
\hline & $\begin{array}{l}\text { Swamp Lake (Batch- } \\
\text { elder) }\end{array}$ & Tuolumne & 6420 & 1957 & Lake sediment & 3 & Batchelder 1980 \\
\hline & $\begin{array}{l}\text { Swamp Lake, } \\
\text { Yosemite }\end{array}$ & Tuolumne & 5018 & 1529 & Lake sediment & 5 & $\begin{array}{l}\text { Smith 1989, unpubl.; } \\
\text { Smith \& Anderson } 1992\end{array}$ \\
\hline 62 & Taylor Marsh & El Dorado & 6229 & 1899 & Lake sediment & 1 & West, unpubl. \\
\hline 63 & Ten Lakes \#3 & Tuolumne & 9020 & 2749 & Lake sediment & 3 & Anderson 1987, unpubl. \\
\hline 64 & Tioga Pass Pond & Mono & 9900 & 3018 & Lake sediment & 4 & $\begin{array}{l}\text { Anderson 1990; Anderson } \\
\text { 1996; Anderson \& Smith } \\
1994\end{array}$ \\
\hline 65 & Tuolumne Meadows & Tuolumne & 8500 & 2591 & Charcoal & 1 & Wood 1975 \\
\hline 66 & Upper Cabin Meadow & Fresno & 7040 & 2146 & Wood & 3 & $\begin{array}{l}\text { Brandau \& Nokes 1975; } \\
\text { Wood } 1975\end{array}$ \\
\hline 67 & Upper Echo Lake & El Dorado & 7420 & 2262 & Lake sediment & 1 & Adam 1985 \\
\hline 68 & Wawona Meadow & Mariposa & 4150 & 1265 & Meadow sediment & 3 & $\begin{array}{l}\text { Anderson, unpubl.; Ander- } \\
\text { son \& Carpenter } 1991\end{array}$ \\
\hline 69 & Well Meadow & Mariposa & 7000 & 2134 & Meadow sediment & 1 & Anderson, unpubl. \\
\hline 70 & Weston Meadow & Tulare & 6680 & 2036 & Meadow sediment & 7 & $\begin{array}{l}\text { Anderson 1996; Anderson } \\
\text { \& Smith 1994; Anderson } \\
\text { \& Smith } 1997\end{array}$ \\
\hline 71 & Willow Root Meadow & Tulare & 7820 & 2384 & Meadow organics & 1 & Anderson, unpubl. \\
\hline 72 & Woski Pond & Mariposa & 3955 & 1205 & Lake sediment & 3 & $\begin{array}{l}\text { Anderson \& Carpenter } \\
1991\end{array}$ \\
\hline
\end{tabular}

